\title{
Diallyl Sulfide-Mediated Modulation of the Fatty Acid Synthase (FASN) Leads to Cancer Cell Death in BaP-Induced Lung Carcinogenesis in Swiss Mice
}

This article was published in the following Dove Press journal:

Journal of Inflammation Research

\begin{abstract}
Arif Khan $\mathbb{D}^{1, *}$
Fahad A Alhumaydhi (D) ${ }^{2}$

Ameen SS Alwashmi (D) ${ }^{2}$

Khaled S Allemailem (iD) ${ }^{2}$

Mohammed A Alsahli ${ }^{2}$

Faris A Alrumaihi $\left(\mathbb{D}^{2}\right.$

Ahmad Almatroudi ${ }^{2}$

Mugahid A Mobark ${ }^{3,4}$

Ayman Mousa $\left(\mathbb{D}^{1,5}\right.$

Masood A Khan (D),*

'Department of Basic Health Sciences, College of Applied Medical Sciences,

Qassim University, Al-Qassim, Buraydah,

Saudi Arabia; ${ }^{2}$ Department of Medical

Laboratories, College of Applied Medical

Sciences, Qassim University, Al-Qassim,

Buraydah, Saudi Arabia; ${ }^{3}$ Department of

Pharmacy Practice, College of Pharmacy, Qassim University, Al-Qassim, Buraydah,

Saudi Arabia; ${ }^{4}$ Department of Pathology,

Faculty of Medicine, University of Kordofan, El-Obeid, Sudan; ${ }^{5}$ Department of Histology and Cell Biology, Faculty of Medicine, Benha University, Benha, Egypt
\end{abstract}

*These authors contributed equally to this work

Correspondence: Arif Khan

Department of Basic Health Sciences,

College of Applied Medical Sciences,

Qassim University, Buraydah, Saudi Arabia

Tel +966590038460

Email arifbiotech@gmail.com

Masood A Khan

Department of Basic Health Sciences,

College of Applied Medical Sciences,

Qassim University, Buraydah, Saudi Arabia

Tel +966507059437

Email masakhan@gmail.com
Purpose: Diallyl sulfide (DAS), one of the organo-sulfur secondary metabolites in garlic, has been shown to inhibit the proliferation of cancer cells. The present study aimed to evaluate the mechanism of DAS in the prevention of benzo[a]pyrene (BaP)-induced lung cancer in a murine model.

Materials and Methods: The mice were exposed to $50 \mathrm{mg} / \mathrm{kg}$ of BaP twice a week for 4 weeks in order to induce lung carcinoma. Pretreatment of mice with DAS $(100 \mathrm{mg} / \mathrm{kg})$ was started 2 weeks before BaP exposure and further continued for 21 weeks. The effect of DAS and $\mathrm{BaP}$ was evaluated by studying various parameters in the serum and tissues of the treated or untreated BaP-exposed mice.

Results: The histopathological findings demonstrated that DAS prevented the progression of malignant lung cancer and metastasis in the liver. A significant drop was observed in BaPinduced tumor marker enzymes (ADA, AHH, $\gamma-\mathrm{GT}, \mathrm{LDH})$ in the serum of the mice treated with DAS. Moreover, DAS treatment resulted in the recovery of antioxidant enzymes, SOD and CAT, in BaP-exposed mice. The induction of apoptosis and the destruction of cellular ROS were detected in cancer cells from the mice pre-treated with DAS. The immunohistochemical analysis revealed the up-regulation of fatty acid synthase (FASN) in the lungs and liver tissues of BaP-exposed mice and the treatment with DAS inhibited FASN expression. Conclusion: The findings of the present study indicated that DAS-induced apoptosis is strongly associated with the downregulation of FASN in tumor tissues. To the best of our knowledge, this is the first study that describes the role of FASN in BaP-induced lung carcinogenesis.

Keywords: DAS, FASN, apoptosis, ROS, lung carcinoma

\section{Introduction}

Lung cancer is recognized as one of the commonly diagnosed cancer and the primary causes of mortality globally. According to GLOBOCAN 2018, more than 2 million cases of lung cancer were registered, making up to $18.4 \%$ of total cancer deaths during 2109. ${ }^{1}$ In recent times, there has also been a massive increase in smoking among males and females in countries like India, China, and Saudi Arabia, which is the leading cause of lung cancer. ${ }^{2,3}$ The exposure of tobacco is associated with about $90 \%$ of total lung cancer cases, and the smokers have a 20 -fold high risk in cancer progression as compared to non-smokers. ${ }^{4,5}$ Benzo[a]pyrene (BaP), 
a polycyclic hydrocarbon found in tobacco smoke, is one of the leading causes in the etiology of lung cancer. The $\mathrm{BaP}$ makes the DNA adduct formation followed by the promotion and progression of cancer after metabolically activated into 7.8-diol-9, 10-epoxide reacting with DNA primarily. ${ }^{6}$ Therefore, the $\mathrm{BaP}$ has been used in all three stages (Initiation, Promotion, and Progression) of the lung cancer model in laboratory animals. A high level of FASN expression has been reported to play a significant role in the promotion, as well as the progression of cancer while controlling the genes associated with malignant transformation. ${ }^{7,8}$ Moreover, the up-regulation of FASN has been described to express in the initiation and progression of non-small cell lung cancer and squamous cell carcinoma. ${ }^{9,10}$

The researchers have been trying to develop the novel anti-cancer agents with high chemotherapeutic outputs and reduce side effects. However, there is no medicine to eradicate cancer, but the risk can be reduced by limiting the process of carcinogenesis. Herbal medicine has engrossed widespread attention as the perception has grown that the nutraceuticals exert a significant role in making the strategies by drug designer against the disease, reviewed by several researchers. ${ }^{11-13}$ The data from several epidemiological studies have demonstrated that the intake of garlic plays an important in the prevention of various diseases, including different types of cancer. ${ }^{14-18}$ The occurrence of organosulfur compounds in the form of allicin has been widely associated with the potential health benefits of garlic. As the allicin is unstable, it is metabolized naturally to various oilsoluble allyl sulfides, such as diallyl sulfide (DAS), diallyl disulfide (DADS), and diallyl trisulfide (DATS).${ }^{19-22}$ The concentration of DAS among other organosulfur secondary metabolites in garlic is minimum, but it showed the lowest toxicity in experimental animals while given orally $\left(\mathrm{LD}_{50}>2000 \mathrm{mg} / \mathrm{kg}\right.$ b.w). Moreover, the higher stability of DAS in comparison to DADS and DATS at room temperature makes it broad-spectrum pharmaceuticals. ${ }^{23}$ Earlier DAS has been shown to diminish the bleomycin-induced pulmonary fibrosis, gentamycin-induced nephrotoxicity by accelerating the antioxidants and impeding inflammatory cytokines. ${ }^{24,25}$ Many studies have demonstrated the possible molecular targets of DAS and try to establish cellular signaling associated with its chemopreventive, as well as chemotherapeutic potential. Noticeably, the chemopreventive effect of DAS was found to be conferred mainly through its antioxidant and antiinflammatory characteristics both in vitro and in vivo as well. DAS appears to function as a chemopreventive agent through multiple mechanisms in different types of cancer. $^{26-28}$

In the present study, we investigated the protective role of DAS in the BaP-induced carcinogenesis. We also evaluated the modulation in the expression of FASN in the lung cancer progression by BaP and chemoprevention with DAS.

\section{Materials and Methods}

\section{Reagents}

The Adenosine Deaminase (ADA), Lactate Dehydrogenase (LDH), Gamma Glutamyl Transferase (GGT), 5'-Nucleotidase (CD73) activity assay kit, Annexin V-FITC/PI, DCFDA/H2DCFDA-Cellular ROS Assay, Mouse- and rabbit-specific HRP/DAB (ABC) detection IHC kits, antibodies (Abs) against FASN, $\beta$ actin, Rabbit anti-mouse horseradish peroxidase, and goat anti-rabbit horseradish peroxidase-conjugated secondary antibodies, Benzo[a]pyrene (BaP) were purchased from Abcam (Cambridge, USA). Fatty acid synthase primary antibody was procured from Santa Cruz Biotechnology (Heidelberg, Germany).

\section{Mice}

Female Swiss mice (10-12 weeks) were obtained from the animal house facility of the King Saud University, Riyadh, Saudi Arabia. The experiments involving the animals were carried out after the approval of the animal ethics committee of the College of Applied Medical Sciences, Qassim University, following guidelines of University of London Animal Welfare Society, Wheathastead, England.

\section{Experimental Design}

Mice were randomly divided into four groups and each group contained six mice. The treatment plan for the study is shown in Figure 1.

\section{Assessment of Body Weight}

The mice were weighed at the beginning of the experiment and after every 2 weeks during the experimental period, and before sacrifice.

\section{Assessment of Relative Lung Weight}

The relative lung weight (RLW) was measured using the formula as follows. 
Weeks

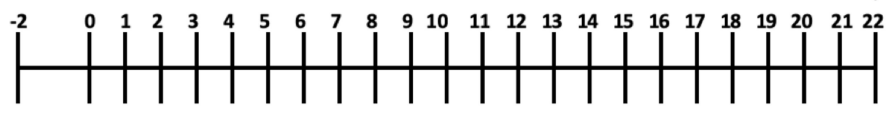

\author{
Vehicle Control (G1) \\ BaP (G2) \\ DAS + BaP (G3) \\ DAS (G4) \\ $200 \mu$ l Corn Oil \\ $50 \mathrm{mg} / \mathrm{kg}$ twice a week \\ $100 \mathrm{mg} / \mathrm{kg}$ thrice a week
}

Figure I Schematic illustration of experimental plan.

Notes: GI mice were given corn oil $(200 \mu \mathrm{L})$ by oral gavage twice a week for 21 weeks. G2 animals were exposed to BaP ( $50 \mathrm{mg} / \mathrm{kg}$ body weight in $200 \mu \mathrm{L}$ corn oil) by oral gavage twice a week for 4 consecutive weeks to develop the lung cancer. G3 (DAS + BaP) mice were given DAS ( $100 \mathrm{mg} / \mathrm{kg}$ body weight in corn oil) was administered orally 2 weeks before the exposure of $\mathrm{BaP}$ as mentioned for $\mathrm{G} 2$, and continued thrice a week for 21 weeks. G4 mice were given DAS as stated for G3 without exposing to BaP to assess the toxicity of DAS.

Abbreviations: BaP, benzo[a]pyrene; DAS, diallyl sulfide; G, group.

$$
R L W=\frac{\text { Lung weight }}{\text { Bodyweight }} X 100
$$

\section{Biochemical Analysis}

The activity of carcinogenesis markers in the serum was determined by the Colorimetric analyses of the ADA, LDH, $\gamma$-GT, 5'-NT, using the kits from Abcam, following manufacturer's instructions.

\section{Antioxidant Enzyme Assays}

The excised lung tissues were homogenized in the assay buffer of respective assay kits to determine SOD, CAT, MDA activity, according to the instruction given by the manufacturer.

\section{Histopathological Evaluation of Lung and Liver Tissues}

The lung and liver tissues were sliced and fixed in $10 \%$ buffered neutral formalin. The formalin-fixed tissues were processed using an automated tissue processor machine (Leica TP1020). The paraffin blocks were sectioned by the rotary microtome (Leica RM2245) to obtain the $4 \mu \mathrm{m} \mathrm{sec}$ tions and stained with hematoxylin and eosin (H\&E). The $\mathrm{H}$ $\&$ E stained tissues were examined under the light microscope (Olympus BX41) at $100 \times, 400 \times \& 640 \times$ magnification, and images were captured using a digital image camera (OMAX A3550U3) built with the ToupView image analyzer. The lungs were examined for the evaluation of malignancy and the changes in malignant cells following pre-treatment with DAS, including their effects on the induction of mitotic activity, malignancy, tumor necrosis, and apoptosis. The liver tissues were evaluated for evidence of metastasis and the potential of the DAS exposure on it.

\section{Terminal Transferase-Mediated dUTP Nick End-Labeling (TUNEL) Assay}

The apoptosis index in the tissues of treated mice was evaluated using in situ BrdU-Red DNA fragmentation (TUNEL) assay kit from the Abcam following the manufacturer's instructions. Briefly, 3-5 $\mu \mathrm{m}$ thick sections of paraffin-embedded tissue on glass slides were deparaffinized and hydrated. The slides were then immersed sequentially in $0.85 \% \mathrm{NaCl}$ and $\mathrm{PBS}$, followed by antigen retrieval by proteinase $\mathrm{K}(10 \mathrm{mg} / \mathrm{mL})$ in Tris- $\mathrm{HCl} \mathrm{pH} 8.0+50 \mathrm{mM}$ EDTA. The tissue samples were then labeled with DNA labeling solution for 1 hour at $37^{\circ} \mathrm{C}$ following the fixation with 4\% paraformaldehyde. After washing, the samples were incubated with anti-BrdU-Red antibody and analyzed by confocal microscopy using $20 \times$ magnification objective, after washing and mounting with fluoroshield solution.

\section{Annexin V-FITC/PI Apoptotic Assay by Flow Cytometry} The changes in the proportion of cells in the viable, necrotic, early, and the late apoptotic stages were 
evaluated using the Annexin V-FITC/PI apoptosis staining kit (Miltenyi Biotec, Germany), by the flow cytometry. Briefly, the single-cell suspension of lungs was prepared using the gentle MACS tissue dissociator (Miltenyi Biotec, Germany), followed by filtering the cells with $70 \mu \mathrm{m}$ mesh cell strainer. The filtered cells were centrifuged at $300 \mathrm{~g}$ for 10 minutes and suspended in the binding buffer. The cells were incubated with Annexin V-FITC for 30 minutes at room temperature followed by the addition of PI before the acquisition of samples. The samples were measured on MACSQuant Analyzer 10 (Miltenyi Biotec, Germany) and analyzed using FlowJo software v10.7.

\section{DCFDA Cellular ROS Assay by Flow Cytometry}

The cellular ROS was measured after harvesting the cells, as stated above. Briefly, the cells were incubated with 20 $\mu \mathrm{M}$ of DCFDA for 30 minutes at $37^{\circ} \mathrm{C}$. The samples were acquired on MACSQuant Analyzer 10 and analyzed using the FlowJo software v10.7.

\section{Immunohistochemical Analysis of FASN in Lung and Liver Tissues}

The changes in the expression of FASN in the alveolar cells of the lung and hepatocytes of the liver were detected using the $\mathrm{ABC}$ detection IHC kit from Abcam. Briefly, 3-5 $\mu \mathrm{m}$ thick sections of paraffinembedded tissue on glass slides were deparaffinized and hydrated, followed by antigen retrieval by citrate buffer method as described earlier by Hussien et al $2020 .^{29}$ The sections from the lung and liver were incubated in $3 \% \mathrm{H} 2 \mathrm{O} 2,5 \%$ bovine serum albumin, anti (FASN) primary antibodies at $4{ }^{\circ} \mathrm{C}$ overnight then antirabbit biotinylated secondary antibody. The reaction was visualized with $\mathrm{DAB}$, counterstained with Mayer's hematoxylin, and observed as a dark brown color in the cytoplasm of the alveolar cells and hepatocytes. The negative control was obtained by omitting the primary antibody while the positive control of FASN was breast cancer tissue of the mouse.

\section{Statistical Analysis}

The mean values and standard errors for all samples were calculated for different treated groups. The significant difference between the groups was measured by the Oneway and Two-way ANOVA, Tukey's multiple comparison tests using Prism 8 . P-value $<0.05$ was considered statistically significant.

\section{Results}

\section{The Effect of BaP and DAS on Body Weight and RLW}

The data showed a significant reduction in the body weight of BaP-exposed mice as compared to vehicle control mice ( $>0.05$ ), whereas no significant changes were measured in the mice pre-treated with DAS or DAS alone (Figure $2 A)$. The increase in RLW was recorded more than $47 \%$ $(p<0.0001)$ in G2, while comparing with G1 mice (Figure 2B). Noticeably, no mortality was observed in any of the treated group.

\section{Effect of DAS on BaP-Induced Tumor Markers in the Serum}

The changes in the activity of various serum marker enzymes, including ADA, AHH, $\mu \gamma-\mathrm{GT}, 5^{\prime}-\mathrm{NT}$, and LDH were analyzed. We observed a significant upsurge $(\mathrm{p}<0.0001)$ in the mice exposed to $\mathrm{BaP}$ as compared to vehicle control (Figure 3). The pre-treatment of DAS significantly reduced the levels of enzymes $(p<0.0001)$ in BaP-exposed mice. The ADA was induced to 2.7 units in Group 2 (G2) mice as compared to 1.5 in Group 1 (G1) mice, whereas it was alleviated by DAS as recorded 1.9 in Group 3 (G3) mice (Figure 3A). The AHH was measured 1.154 in G2 from 0.493 in G1, dropped to 0.683 in G3 mice (Figure 3B). The $\gamma$-GT was raised to 1.91 units in G2 as compared to 1.067 in G1 mice, whereas it decreased to 1.340 treated in G3 mice (Figure 3C). Similarly, 5'-NT and LDH activities stirred to 2.667 and 1.1 units in G2 mice as compared to 1.373 and 1.1 in G1 mice, respectively (Figure 3D). As shown in Figure 3E, the treatment of DAS (G3) lessened to 1.81 (5'-NT) and $1.33(\mathrm{LDH})$, correspondingly. The mice treated with DAS alone (G4) showed no changes compared to G1 in the activity of any of the enzymes.

\section{Effect of DAS on Antioxidants (SOD, CAT, and MDA) in BaP-Induced Lung Carcinogenesis}

The data revealed a significant reduction in the level of SOD and CAT measured in the G2 mice as compared to G1 mice $(p<0.0001)$. However, the treatment of DAS in G3 recovered the loss of SOD significantly $(p<0.0001)$. The activity of SOD decreased to 2.133 units in the G2 mice, whereas it was measured 4.567 in G1 mice. The BaP-exposed mice treated with DAS showed recovery of 


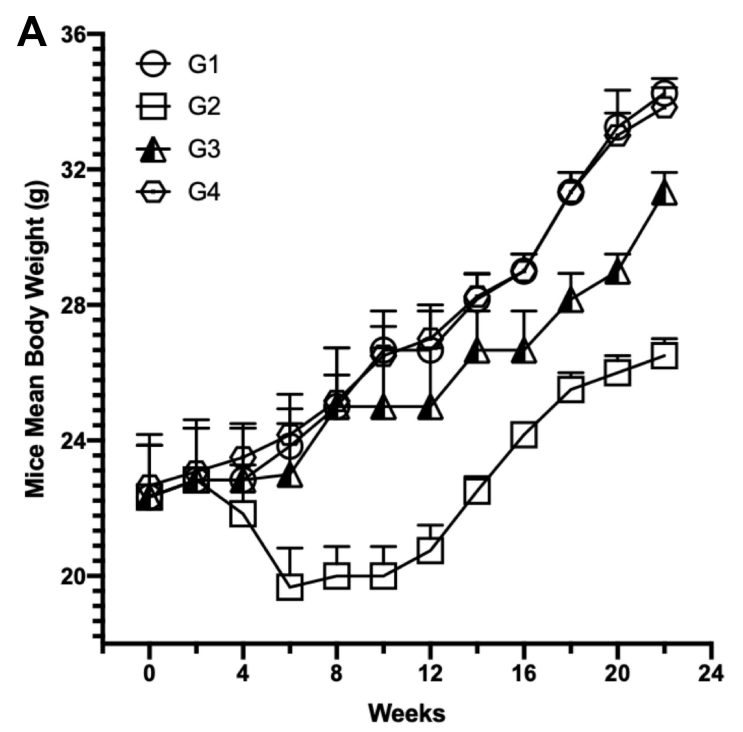

\section{B}

\begin{tabular}{ll} 
Groups & Relative Lung weight (\%) \\
\hline G1 & $0.613 \pm 0.009$ \\
G2 & $0.863 \pm 0.015$ \\
G3 & $0.660 \pm 0.10$ \\
G4 & $0.620 \pm 0.012$
\end{tabular}

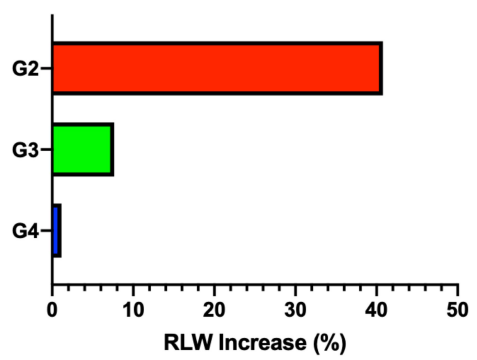

Figure 2 Effect of BaP and DAS on the body weight and RLW.

Notes: (A) The mice were weighed from week zero of the experiment, every 2 weeks during the experimental period, and before sacrifice. (B) The RLW was measured using the formula as described in materials and methods after sacrificing the mice at the end of the experiment. The values are presented as mean \pm SE of six mice for each group. $\mathrm{p}<0.0182$, as compared with $\mathrm{G} 2$ and $\mathrm{G} 3$.

Abbreviations: RLW, relative lung weight; SE, standard error.
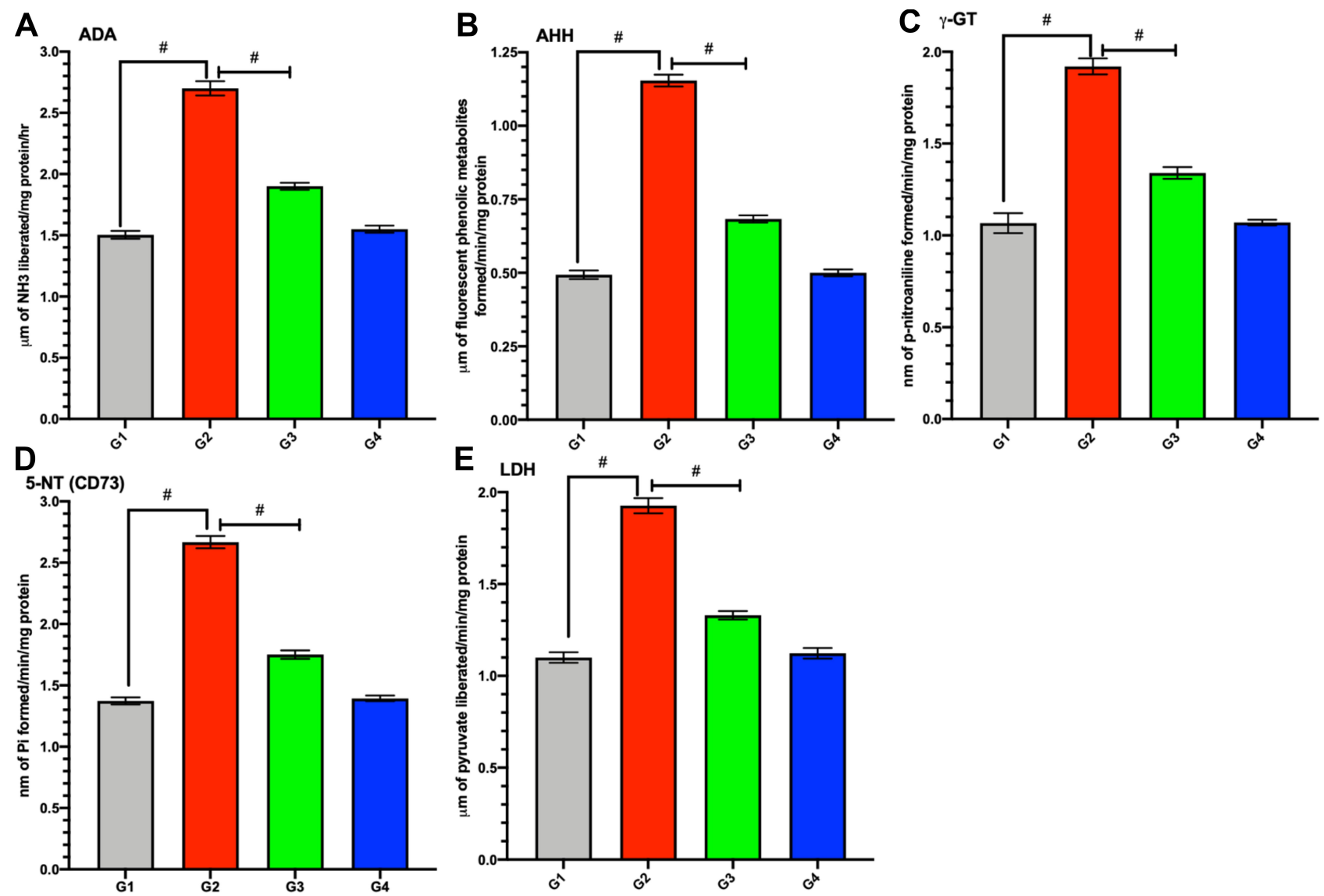

Figure 3 Effect of BaP and DAS on the activity tumor marker enzymes in the serum.

Notes: (A) ADA, (B) AHH, (C) $\gamma$-GT, (D) 5'-NT, (E) LDH. The activities of the tumor marker enzymes in the serum were measured colorimetrically using the kit for the respective enzymes. The values are expressed as mean \pm SE of three independent experiments. ${ }^{\#} \mathrm{p}<0.000 \mathrm{I}$ between the respective groups.

Abbreviations: ADA, adenosine deaminase; AHH, aryl hydrocarbon hydroxylase; $\gamma$-GT, gamma glutamyl transferase; 5'-NT, 5'-nucleotidase; LDH, lactate dehydrogenase. 

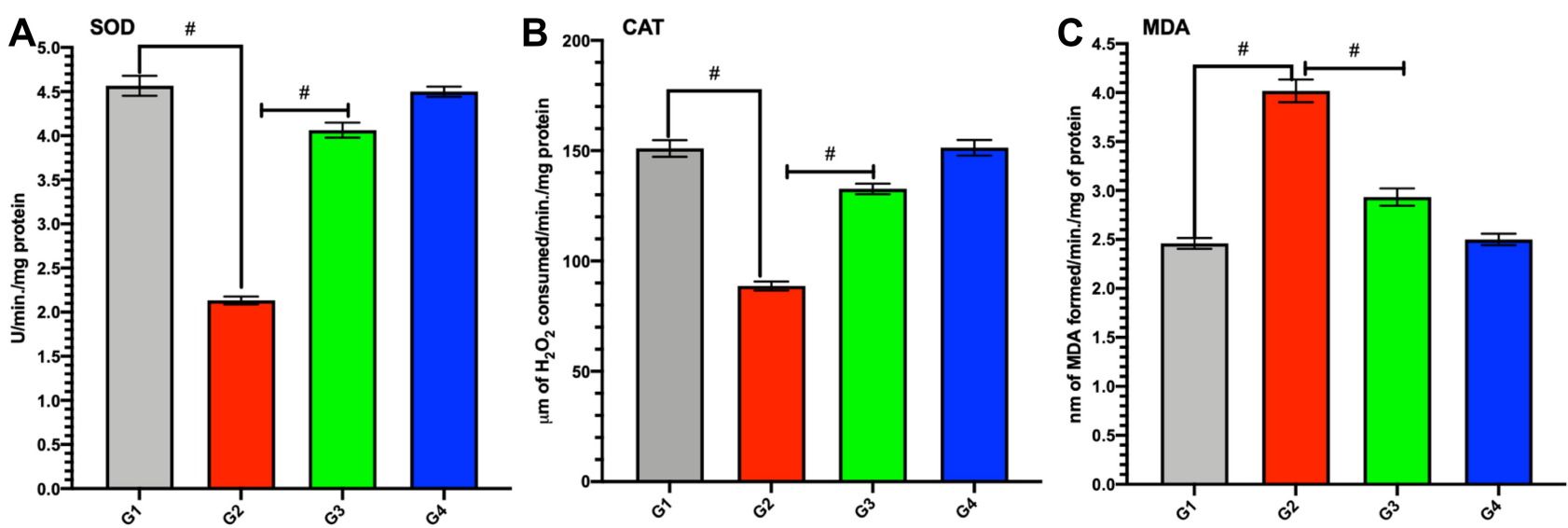

Figure 4 Effect of DAS on the level of antioxidant in lung tissue.

Notes: (A) SOD, (B) CAT, (C) MAD. The level of enzymes was detected colorimetrically in the lungs using the kits after homogenizing the tissues in the buffer of respective assay. The values are expressed as mean \pm SE of three independent experiments. ${ }^{\#} p<0.000$ I between the respective groups.

Abbreviations: SOD, superoxide dismutase; CAT, catalase; MDA, malondialdehyde dehydrogenase.

SOD to 4.063 (Figure 4A). As depicted in Figure 4B, the activity of CAT decreased to 88.667 by BaP as compared to 151.0 units in $\mathrm{G} 1$ mice, whereas it was improved to 132.667 in G3 mice. Figure 4C demonstrated that the concentration of MDA significantly raised to 4.017 units in G2 mice as compared to $2.46(\mathrm{p}<0.0001)$ in G1 mice. The treatment of DAS significantly lessened to 2.93 $(p<0.0001)$ in G3 mice as compared to 4.017 units in G2 mice.

\section{Effect of DAS on the Histopathology of Lung and Liver}

The microscopic examination of the $\mathrm{BaP}$ induced lung cancer sections from G2 demonstrated the clusters of tumors that consist of a diffuse sheet of small malignant cells with scan frequent necrosis. The compression in the adjacent alveolar spaces and preserved bronchioles, lined by ciliated pseudostratified columnar epithelium, were also seen (Figure 5A, Supplementary Figure 1 (S1)). The lungs from the mice pre-treated with DAS (G3) showed an abundance of apoptotic malignant cells. It exhibited scattered malignant cells in the small focal area, whereas the ghost of malignant cells with preserved alveolar spaces and alveolar ducts (Figure 5A). The liver section in G2 mice showed the sheets of metastatic small malignant cells, including scant cytoplasm and frequent mitosis with evidence of vascular invasion (Figure 5B, Supplementary Figure 1 (S1)). Interestingly, the disappearance of invading sheets of malignant cells, some of the scattered apoptotic cells, and focal areas of necrosis were noticed in the liver sections from the G3 mice
(Figure 5B). The histopathological analysis clearly indicated the normal architecture of the tissues in G1 and G4 mice (Figure 5).

\section{Terminal Transferase-Mediated dUTP Nick End-Labeling (TUNEL) Assay}

The data of the BrdU TUNEL assay revealed that the pretreatment of DAS induced the apoptosis in lung sections as the relative apoptotic index (RAI) was measured to be 1.534. As depicted in Figure 6, no induction was observed in the G1, G4, G2 mice lung cancer sections.

\section{Annexin V-FITC/PI Apoptosis Imaging Analysis by Confocal Microscopy}

The results of the flow cytometry assay confirmed the previous analysis as the induction of apoptosis was seen in the lung cancer, pre-treated with DAS. It was found to be $>24 \%$ in the G3 mice. As shown in Figure 7, the early and late apoptosis were measured to be 3.59 and $20.9 \%$ in the lungs of the G3 mice. Remarkably, no significant induction of apoptosis was noticed in the lung sections from G1, G2, and G4 mice as well.

\section{DCFDA Cellular ROS Assay by Flow Cytometry}

The generation of ROS by $\mathrm{BaP}$ in lung cancer was recorded to be $126,684.667$ MFI of DCFDA, whereas it was found to be 64.267 MFI in G1 mice. The significant reduction in the level of cellular ROS (45,473.0 MFI) was noticed in the G3 $(\mathrm{p}<0.0001)$ mice (Figure 8). 

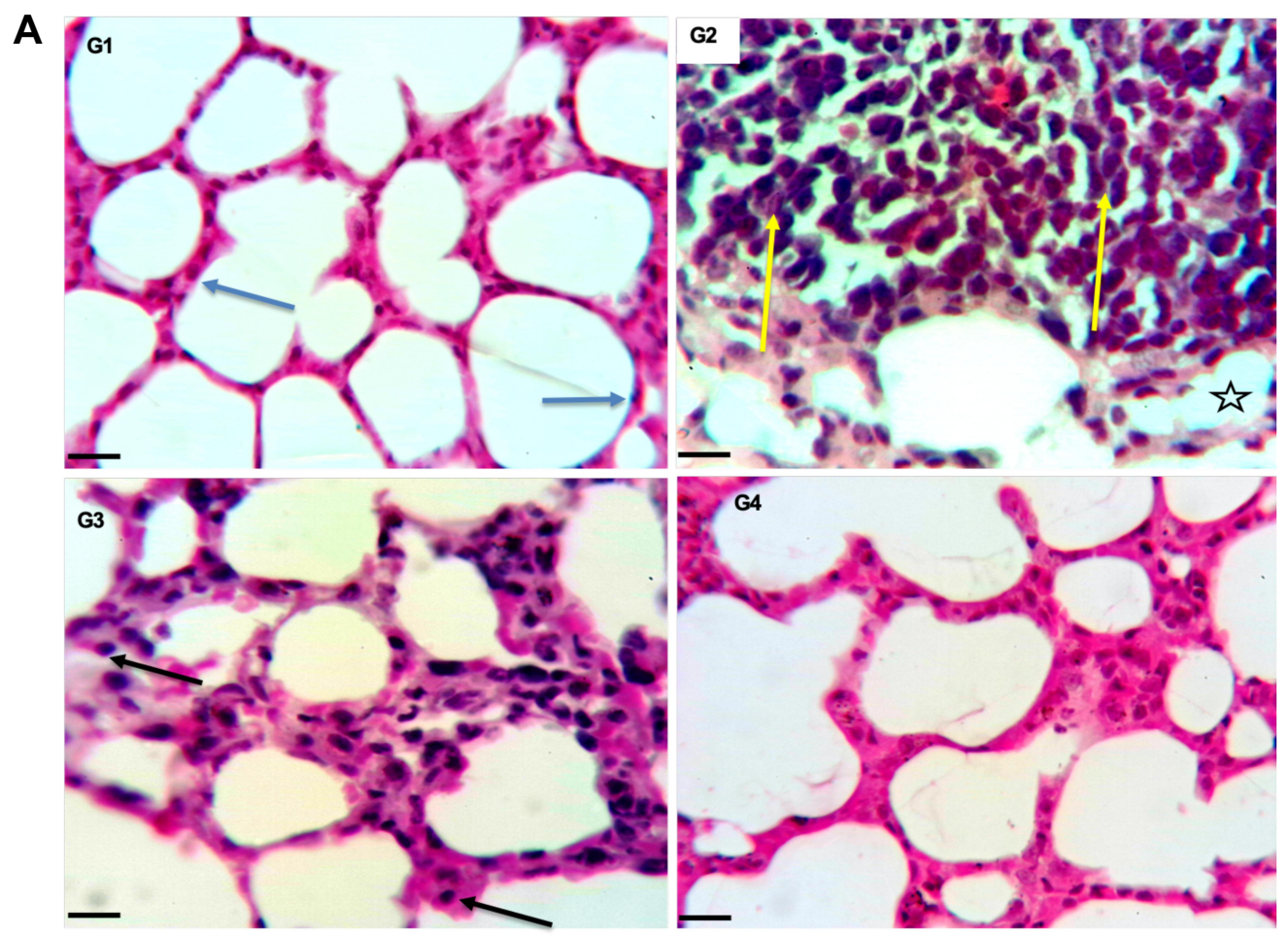

B
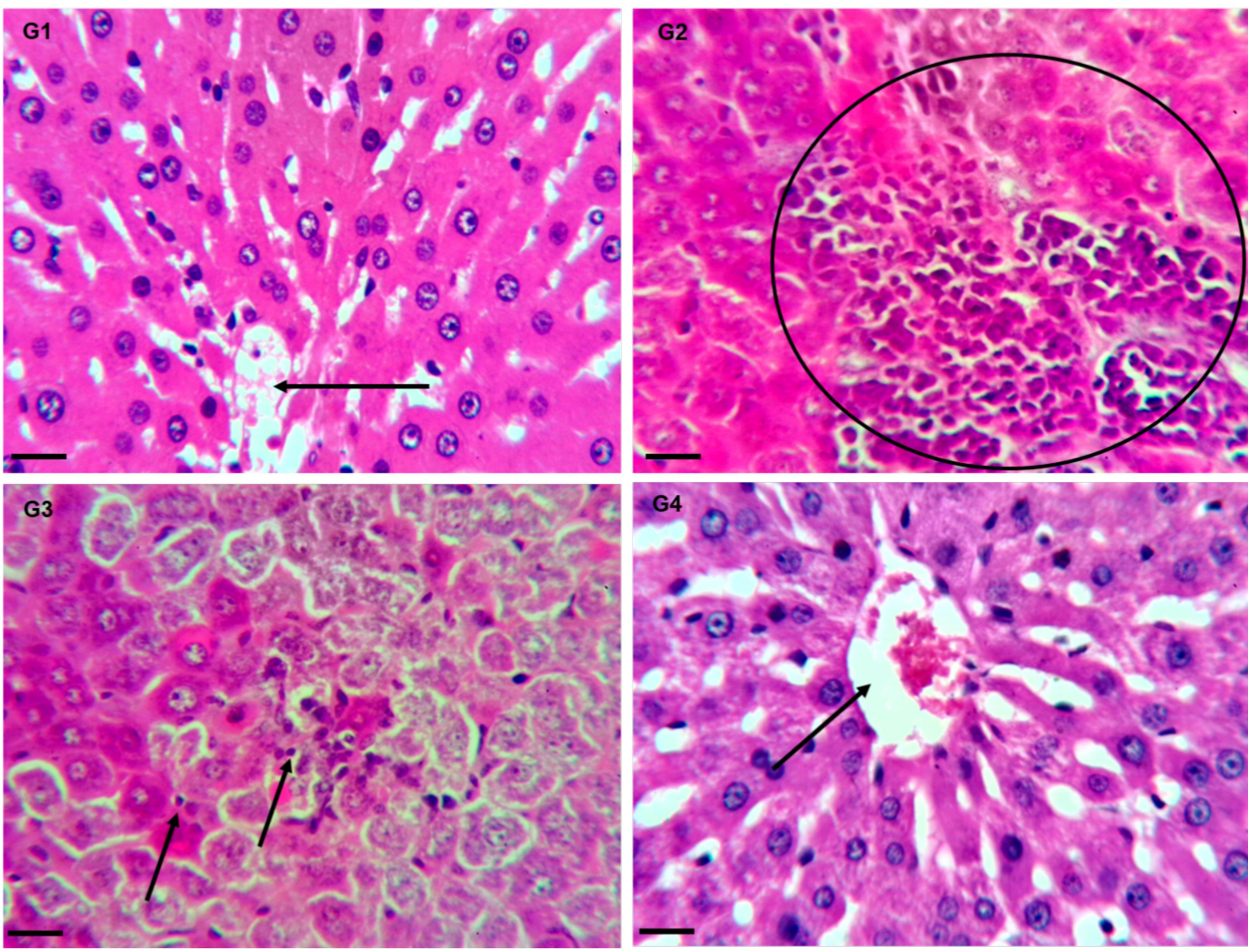

Figure 5 Effect of DAS on the histopathology of lungs and liver.

Notes: The representative H\&E stained images of: (A) Lungs: GI is showing mature honeycomb-like structure of AV spaces, lined by flat pneumocytes (blue arrows). G2 image confirms the small cell lung cancer as it shows the clusters of tumor that consist of diffuse sheet of small round to fusiform MCs with scant cytoplasm (yellow arrows). The adjacent AV spaces are compressed (star). G3 shows scanty small MCs with scant cytoplasm beside intact AV spaces. Apoptotic cells are noted (black arrows). G4 shows no change as similar to GI. (B) Liver: GI is showing intact tissue architecture composed of distinct HE with preserved sinusoidal spaces all arranged around the CV (black arrows). G2 shows cluster of metastatic small rounded to fusiform MCs with scant cytoplasm and frequent mitosis (circle). G3 is showing only few scattered apoptotic cells (black arrow) and focal areas of necrosis (blue arrow) with disappearance of invading sheets of MCs. G4 liver is showing intact tissue architecture composed of distinct HE with preserved sinusoidal spaces all arranged around a CV (black arrow). H\&E staining, 640x, bar $=30 \mu \mathrm{m}$.

Abbreviations: $\mathrm{H} \& E$, hematoxylin and eosin; $A V$, alveoli; MCs, malignant cells; CV, central vein; $H E$, hepatocytes. 

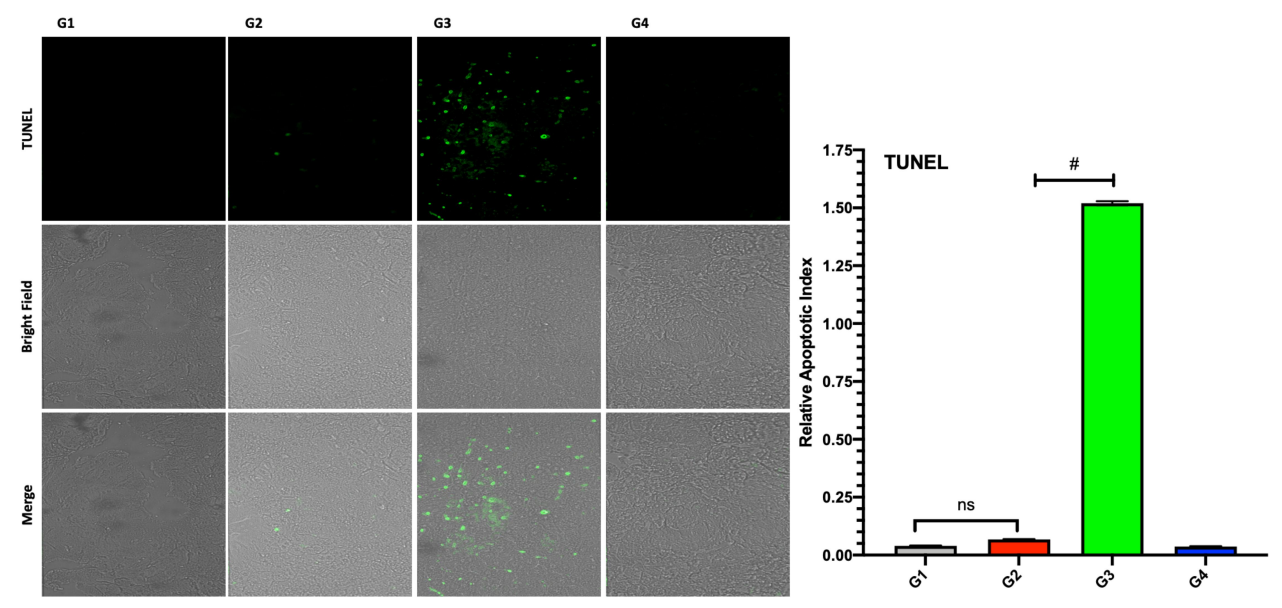

Figure 6 Effect of DAS on BaP-induced apoptotic index in lung tissue.

Notes: The representative images are showing the apoptotic cells detected using TUNEL assay kit by confocal image analysis. The values are expressed as RAI mean \pm SE of three independent experiments. NS No significance GI vs G2, ${ }^{\#}<0.000$ I G2 vs G3.

Abbreviations: TUNEL, terminal deoxynucleotidyl transferase dUTP nick end labeling; RAI, relative apoptotic index.
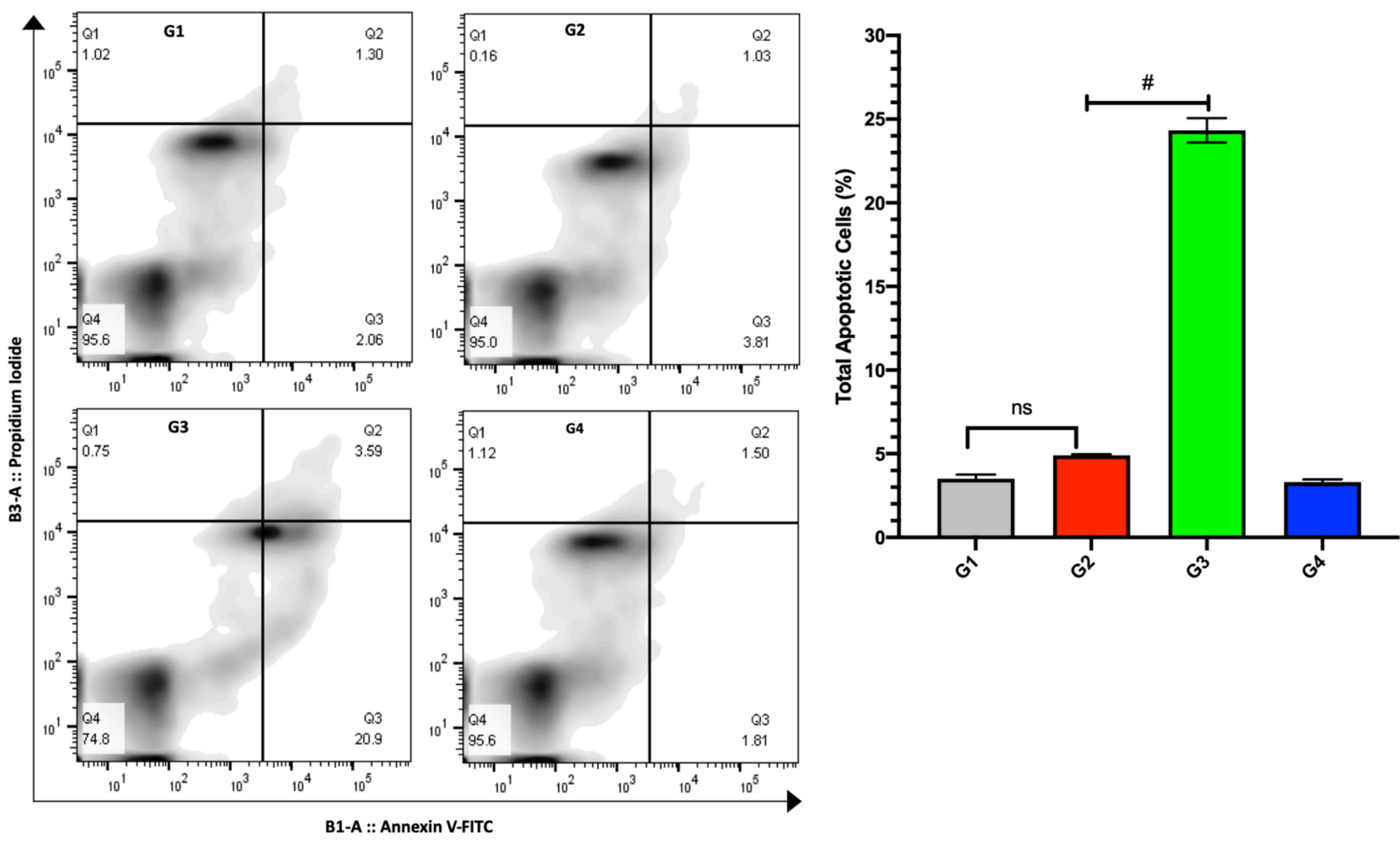

Figure 7 Effect of DAS on BaP-induced apoptosis in lung cells by flow cytometry.

Notes: The changes in the proportion of cells in the viable, early, and late apoptotic stages were evaluated using Annexin V-FITC/PI apoptosis staining kit. The values are expressed as mean \pm SE of three independent experiments. ${ }^{N S}$ No significance GI vs G2, ${ }^{\#}<0.000$ I G2 vs G3.

Effect of DAS on the Expression of FASN by Immunohistochemical Analysis

The upregulation of FASN was seen in the lung alveoli and liver hepatocytes around the central veins, along with malignancy in $\mathrm{G} 2$ mice as relative cytoplasmic immunoexpression (ICE) of FASN was measured more than 8.167 and 4.667, respectively. A significant reduction was observed in G3 $(\mathrm{p}<0.0001)$ mice as relative ICE was recorded 3.93 in lung alveoli and 1.9 in hepatocytes (Figure 9).

\section{Discussion}

The use of natural products in the prevention as well as treatment of various types of cancer, including lung cancer, has opened the multiple windows for the designing of 


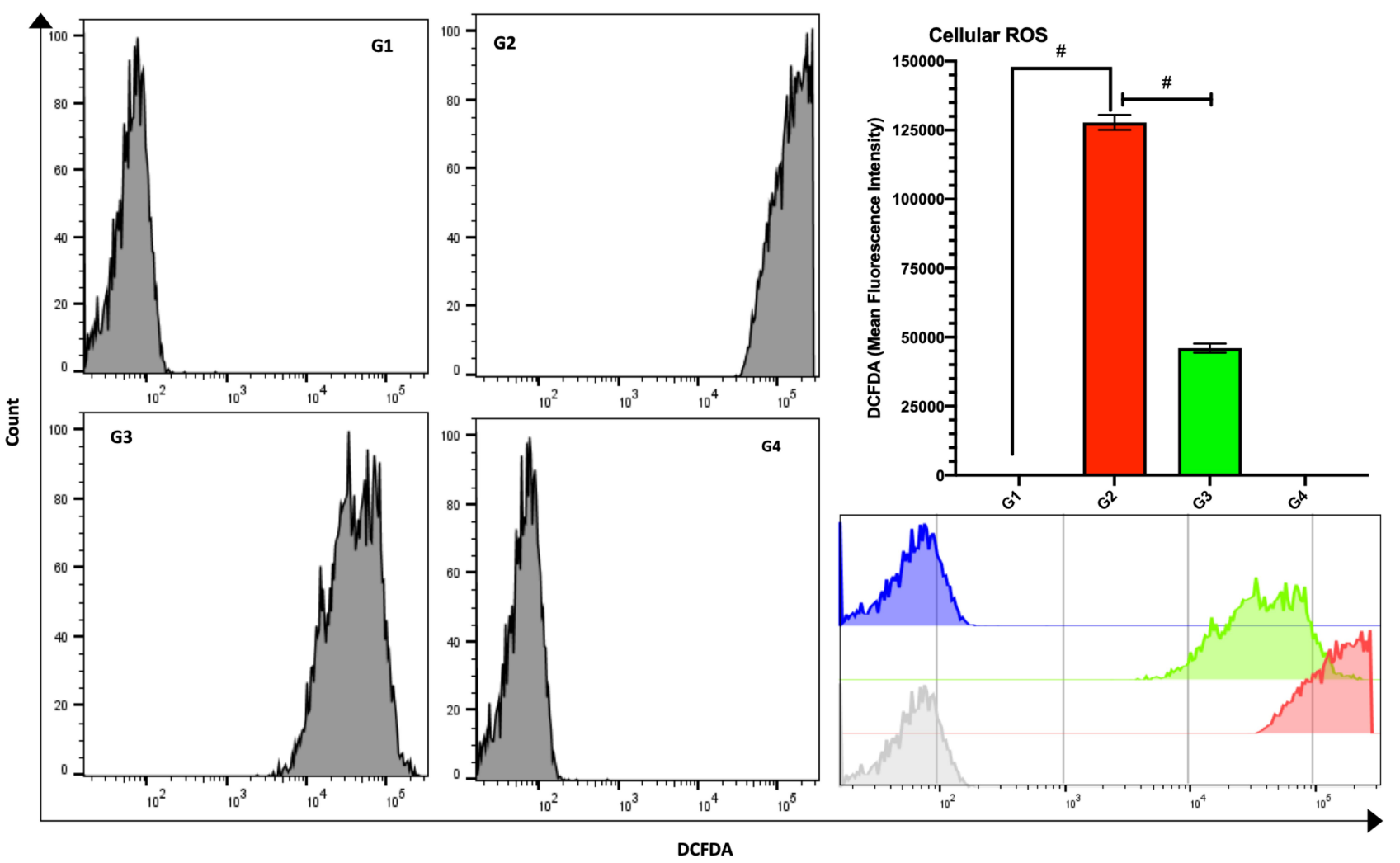

Figure 8 Effect of DAS on BaP-induced cellular ROS in lung cells by flow cytometry.

Notes: The cellular ROS was measured in the lung cells were measured by MFI of DCFDA in flow cytometer. The values are expressed as mean \pm SE of three independent experiments. ${ }^{\#} \mathrm{p}<0.0001$ between the respective groups.

Abbreviations: ROS, reactive oxygen species; MFI, mean fluorescent index; DCFDA, 2',7'-dichlorofluorescin diacetate.

novel drugs. ${ }^{30,31}$ The current study demonstrated the chemopreventive potential of DAS in the BaP-induced lung cancer model. Interestingly, the results also revealed the upregulation of FASN in lung carcinogenesis and metastasis in the liver, downregulated by DAS treatment followed by apoptosis in cancer cells.

As shown in Figure 2, a significant loss in the body weight was recorded in mice exposed to BaP. Several studies suggested that such a drop in the body weight might be occurred due to cancer cachexia. The degeneration of skeletal and adipose tissue of the host body exposed to a carcinogen may cause a continuous reduction in the body weight. Subsequently, the intake or absorption of an inadequate amount of food is also involved in the wasting of muscles in cancer cachexia. ${ }^{32,33}$ However, DAS protected the mice from such loss as there was no change in the body weight in the mice pre-treated with DAS (G3) as compared to vehicle control (G1), clearly indicated its role in the protection from cancer cachexia. A significant increase in the relative lung weight in G2 mice directed us to evaluate the expression of FASN in the tissues as discussed later. The accumulation of inflammatory cells and increased proliferation of cancerous cells are associated with enlarged lungs. ${ }^{34}$ The significant drop in the relative lung weight and increased body weight by DAS were consistent with previous chemopreventive studies of various plant extracts and their active components in chemically induced lung cancer. ${ }^{35-37}$ The histopathological data studies confirmed the tumor growth inhibitory and the protective effect of DAS in the lungs (Figure 5A). The data also revealed that the pretreatment of DAS controlled the invasion of cancer cells in the liver leading to apoptosis (Figure 5B).

The biochemical analyses of several tumor marker enzymes such as ADA, AHH, $\gamma$-GT, 5'-NT, LDH in the serum explicitly indicated the status of the lung and the liver. AHH is one of the critical biomarkers to diagnose lung cancer at an early stage. The exposure of $\mathrm{BaP}$ has been known to induce AHH through the activation of aryl hydrocarbon receptor (AhR), which converts $\mathrm{BaP}$ into BPDE. The transformation of $\mathrm{BaP}$ into BPDE initiates the process of carcinogenesis by DNA adduct 
A
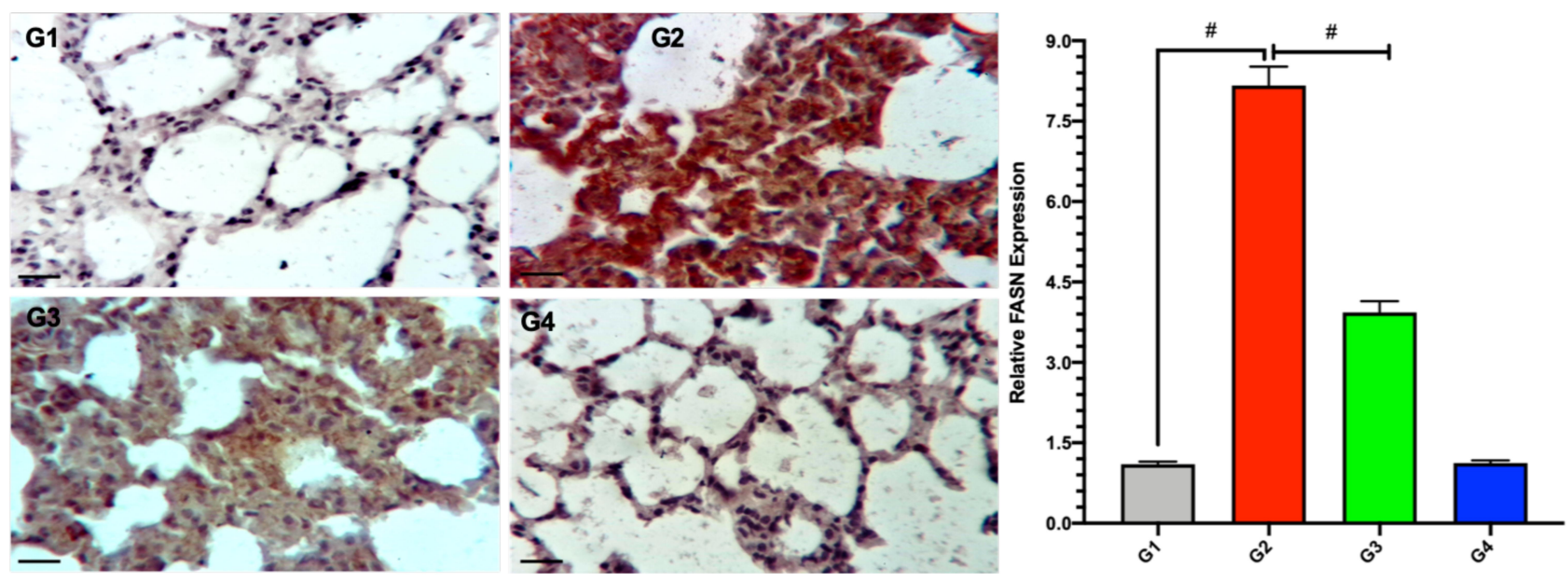

B
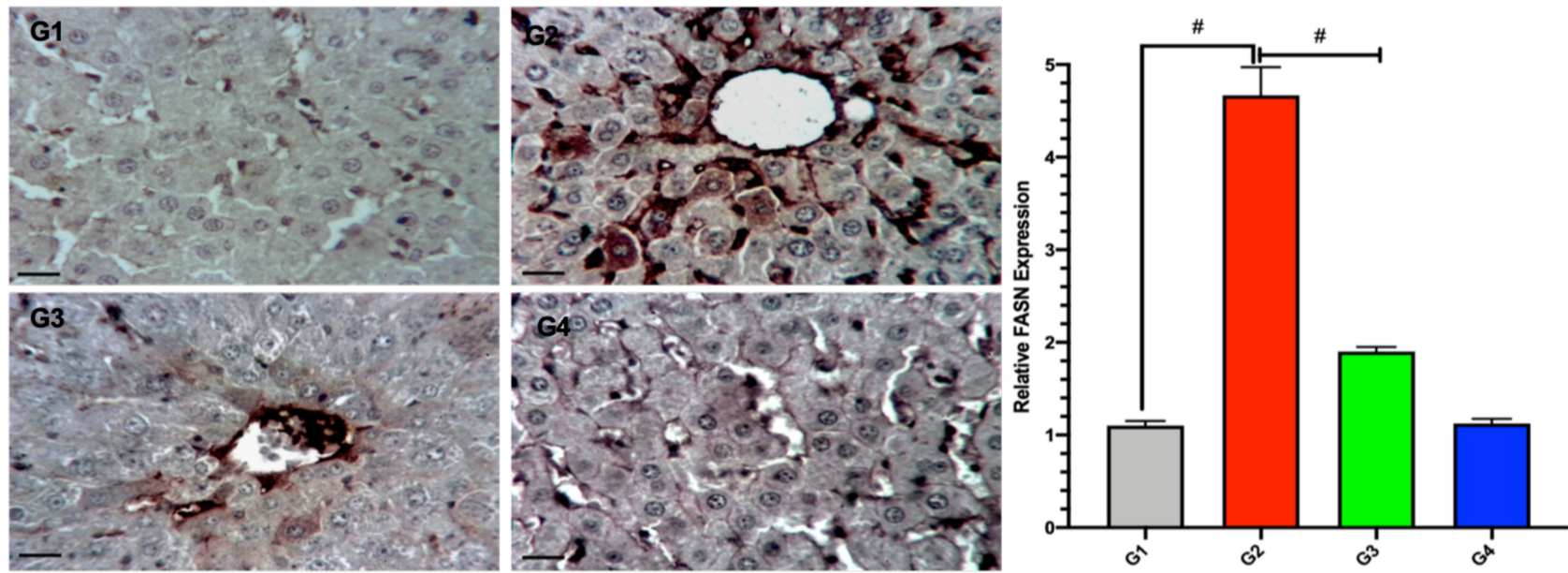

Figure 9 Effect of DAS on the expression of FASN by IHC in lung and liver tissues.

Notes: The representative images of IHC analysis of FASN expression in the: (A) lungs, (B) Liver. The strong upregulation of FASN detected in the lung alveoli and liver hepatocyte around CV in G2 mice, while G3 shows significantly reduced expression. The sections from GI and G2 show weak FASN stain. The values are expressed as relative $\mathrm{CIE}$ mean $\pm \mathrm{SE}$ of three independent experiments. ${ }^{\#} \mathrm{p}<0.000 \mathrm{I}$ between the respective groups. FASN immunostaining, $640 \mathrm{x}$, bar $=30 \mu \mathrm{m}$.

Abbreviations: FASN, fatty acid synthase; IHC, immunohistochemistry.

formation. ${ }^{38-40}$ A significant reduction $(p<0.0001)$ in the activity of AHH by DAS was observed in the serum as compared to BaP-exposed mice. The effect of DAS in the downregulation of CYP1A1 mRNA was reported in the lung and liver induced by methylcholanthrene. ${ }^{41}$ The increased activity of $\gamma$-GT is known to express as a tumor prognosis marker, which also shows the cancer metastasis. Similarly, LDH is also one of the prognostic markers of various cancers as an increased level was measured in cancer malignancies. The activity of LDH controls glycolysis as it is the only energy-producing pathway to accelerate the immortal growth of malignant cells by elevated LDH. ${ }^{42-44}$ The activity of serum ADA has been reported to be increased in lung cancer patients. ${ }^{45}$ It is one of the critical enzymes, which participates in the metabolism of purine in the growing cancer cells. The ADA catalyzes the deamination of adenosine to inosine, which is converted to hypoxanthine after deribosylation. Hypoxanthine is an essential intermediate in the synthesis of purine nucleotides via the salvage pathway. ${ }^{14,46}$ Our results demonstrated that the continuous exposure of DAS significantly drops the level of these enzyme activities in BaP-exposed mice (Figure 3). The results also agreed with the studies that reported the considerable decrease in the chemical carcinogen-induced activities of these tumor marker enzymes by different plant extracts or its active constituents. ${ }^{36,47,48}$ 
The generation of excessive ROS plays a crucial role in the initiation and progression of lung cancer as the lung is directly exposed to environmental pollutants that damage important macromolecules of lungs and other organs as well. MDA is a highly toxic metabolite, produced as one of the end product of lipid peroxidation, transform DNA and proteins by reacting their sulphydryl (-SH) and imino $(=\mathrm{NH})$ groups. $^{49-51}$ The data revealed a significant increase in MDA by BaP, which was protected by the continuous administration of DAS (Figure 4). The preventive effect of DAS in the formation of ROS was also confirmed by measuring the cellular ROS using DCFDA in the flow cytometer (Figure 8).

Various antioxidant enzymes such as SOD and CAT protect the cells from ROS-induced oxidative damage by scavengings free radicals. ${ }^{52,53}$ Mainly, the SOD protects the cells from oxidative stress generated by superoxide anions and lipid peroxidation, whereas CAT is involved in the breakdown of $\mathrm{H}_{2} \mathrm{O}_{2}$ in cancer cells. Several studies reported the reduction in the activity of these enzymes in BaP-exposed mice. ${ }^{54,55} \mathrm{We}$ observed the activation of antioxidant enzymes by regular exposure of DAS as their activity was significantly dropped in BaP-exposed mice (Figure 4).

Apoptosis is a programmed cell death associated with tissue homeostasis for the removal of abnormal cells. The changes in the expression of pro- and anti-apoptotic genes play an important role in the process of carcinogenesis due to immortal proliferation and impaired apoptosis. ${ }^{56,57}$ Our results exhibited the induction of apoptosis in the malignant cells by DAS, initially noticed by the histopathology of lung and liver (Figure 5). These findings were also confirmed by measuring the ratio of apoptotic cell and apoptotic index by Annexin V-FITC in a flow cytometer and TUNEL, respectively (Figures 6 and 7). The expression of fatty acid synthase has been found to be upregulated in the carcinogen-induced lung cancer model. ${ }^{58}$ We also detected the high level of FASN in the lungs and liver sections of the BaP-exposed mice. Remarkably, a significant reduction in the expression of FASN was recorded in the mice treated with DAS (Figure 9). Several studies, including the molecular docking method, suggested the cholesterol-lowering effect of garlic and organosulfur compound by inhibiting FASN.$^{59,60}$ The use of polyphenols has been reported to minimize the risk of cancer by inhibiting FASN activity. Several studies also suggested the flavonoid-mediated inhibition of FASN induces apoptosis and inhibits cancer cell proliferation as well. Thus, the down-regulation of FASN, leading to apoptosis, maybe one of the molecular events responsible for the chemopreventive effect of DAS.

\section{Conclusion}

The results of the present study support the potential chemopreventive effect of DAS in the process of lung carcinogenesis. The present study indicates that the efficacy of DAS to induce apoptosis is strongly associated with the downregulation of FASN. For the best of our knowledge, this is also the first study that demonstrates the role of FASN in BaP-induced lung cancer. Further analysis is required to understand the chemotherapeutic and the synergistic effect of DAS, including the detailed involvement of FASN-dependent and -independent pathways in the lung cancer system.

\section{Acknowledgments}

The authors gratefully acknowledge the Deanship of Scientific Research, Qassim University, Al-Qassim, Buraydah, Saudi Arabia for the financial support for this research under the Grant \# [cams-2018-1-14-S-3518] during the academic year 2018.

\section{Disclosure}

The authors report no conflicts of interest in this work.

\section{References}

1. Bray F, Ferlay J, Soerjomataram I, Siegel RL, Torre LA, Jemal A. Global cancer statistics 2018: GLOBOCAN estimates of incidence and mortality worldwide for 36 cancers in 185 countries. CA Cancer J Clin. 2018;68(6):394-424.

2. Goss PE, Strasser-Weippl K, Lee-Bychkovsky BL, et al. Challenges to effective cancer control in China, India, and Russia. Lancet Oncol. 2014;15(5):489-538. doi:10.1016/S1470-2045(14)70029-4

3. Siddiqui S, Ogbeide DO. Profile of smoking amongst health staff in a primary care unit at a general hospital in Riyadh, Saudi Arabia. Saudi Med J. 2001;22(12):1101-1104.

4. Dogan S, Shen R, Ang DC, et al. Molecular epidemiology of EGFR and KRAS mutations in 3026 lung adenocarcinomas: higher susceptibility of women to smoking-related KRAS-mutant cancers. Clin Cancer Res. 2012;18(22):6169-6177. doi:10.1158/1078-0432.CCR11-3265

5. Tang L, Lim WY, Eng P, et al. Lung cancer in Chinese women: evidence for an interaction between tobacco smoking and exposure to inhalants in the indoor environment. Environ Health Perspect. 2010;118(9):1257-1260. doi:10.1289/ehp.0901587

6. Osborne MR, Brookes P, Beland FA, Harvey RG. The reaction of ( \pm )-7alpha, 8beta-dihydroxy-9beta, 10beta-epoxy-7,8,9,10tetrahydrobenzo(a)pyrene with DNA. Int $J$ Cancer. 1976;18 (3):362-368. doi:10.1002/ijc.2910180315

7. Migita T, Ruiz S, Fornari A, et al. Fatty acid synthase: a metabolic enzyme and candidate oncogene in prostate cancer. $J$ Natl Cancer Inst. 2009;101(7):519-532. doi:10.1093/jnci/djp030 
8. Patterson AD, Maurhofer O, Beyoglu D, et al. Aberrant lipid metabolism in hepatocellular carcinoma revealed by plasma metabolomics and lipid profiling. Cancer Res. 2011;71(21):6590-6600. doi:10.11 58/0008-5472.CAN-11-0885

9. Ali A, Levantini E, Teo JT, et al. Fatty acid synthase mediates EGFR palmitoylation in EGFR mutated non-small cell lung cancer. EMBO Mol Med. 2018;10(3).

10. Piyathilake CJ, Frost AR, Manne U, et al. The expression of fatty acid synthase (FASE) is an early event in the development and progression of squamous cell carcinoma of the lung. Hum Pathol. 2000;31(9):1068-1073. doi:10.1053/hupa.2000.9842

11. Hou YN, Deng G, Mao JJ. Practical application of "about herbs" website: herbs and dietary supplement use in oncology settings. Cancer J. 2019;25(5):357-366.

12. Luo H, Vong CT, Chen $\mathrm{H}$, et al. Naturally occurring anti-cancer compounds: shining from Chinese herbal medicine. Chin Med. 2019;14(48).

13. Malongane F, McGaw LJ, Mudau FN. The synergistic potential of various teas, herbs and therapeutic drugs in health improvement: a review. J Sci Food Agric. 2017;97(14):4679-4689. doi:10.1002/ jsfa.8472

14. Akyol O, Gökbulut I, Köksal N, Akin H, Ozyurt H, Yildirim Z. The activities of purine catabolizing enzymes in plasma and bronchial washing fluid in patients with lung cancer and pneumonia. Clin Biochem. 2001;34(3):251-254. doi:10.1016/S0009-9120(01) 00203-X

15. Nicastro HL, Ross SA, Milner JA. Garlic and onions: their cancer prevention properties. Cancer Prev Res (Phila). 2015;8(3):181-189. doi:10.1158/1940-6207.CAPR-14-0172

16. Shang A, Cao SY, Xu XY, et al. Bioactive compounds and biological functions of garlic (Allium sativum L.). Foods. 2019;8(7):246. doi:10.3390/foods 8070246

17. Soleimani D, Paknahad Z, Rouhani MH. Therapeutic effects of garlic on hepatic steatosis in nonalcoholic fatty liver disease patients: a randomized clinical trial. Diabetes Metab Syndr Obes. 2020; 13:2389-2397. doi:10.2147/DMSO.S254555

18. El-Saber Batiha G, Magdy BA, G Wasef L, et al. Chemical constituents and pharmacological activities of garlic (allium sativum 1.): a review. Nutrients. 2020;12(3):872. doi:10.3390/nu12030872

19. Cerella C, Dicato M, Jacob C, Diederich M. Chemical properties and mechanisms determining the anti-cancer action of garlic-derived organic sulfur compounds. Anticancer Agents Med Chem. 2011;11 (3):267-271. doi:10.2174/187152011795347522

20. Rose P, Moore PK, Whiteman M, Zhu YZ. An appraisal of developments in allium sulfur chemistry: expanding the pharmacopeia of garlic. Molecules. 2019;24(21):4006. doi:10.3390/molecules24214 006

21. Trio PZ, You S, He X, He J, Sakao K, Hou DX. Chemopreventive functions and molecular mechanisms of garlic organosulfur compounds. Food Funct. 2014;5(5):833-844.

22. Hassan HT. Prospective clinical role for anticancer garlic organosulfur compounds. Anticancer Agents Med Chem. 2011;11(3):247-248. doi:10.2174/187152011795347478

23. Truong D, Hindmarsh W, O'Brien PJ. The molecular mechanisms of diallyl disulfide and diallyl sulfide induced hepatocyte cytotoxicity. Chem Biol Interact. 2009;180(1):79-88. doi:10.1016/j.cbi.2009.02. 008

24. Kalayarasan S, Prabhu PN, Sriram N, Manikandan R, Arumugam M, Sudhandiran G. Diallyl sulfide enhances antioxidants and inhibits inflammation through the activation of $\mathrm{Nrf} 2$ against gentamicin-induced nephrotoxicity in wistar rats. Eur J Pharmacol. 2009;606(1-3):162-171. doi:10.1016/j.ejphar.2008.12.055

25. Kalayarasan S, Sriram N, Sudhandiran G. Diallyl sulfide attenuates bleomycin-induced pulmonary fibrosis: critical role of iNOS, NF-kappaB, TNF-alpha and IL-1beta. Life Sci. 2008;82(2324):1142-1153. doi:10.1016/j.1fs.2008.03.018
26. McCaskill ML, Rogan E, Thomas RD. Diallyl sulfide inhibits diethylstilbestrol induced DNA damage in human breast epithelial cells (MCF-10A). Steroids. 2014;92:96-100. doi:10.1016/j.steroids. 2014.09.005

27. Wargovich MJ, Imada O, Stephens LC. Initiation and post-initiation chemopreventive effects of diallyl sulfide in esophageal carcinogenesis. Cancer Lett. 1992;64(1):39-42. doi:10.1016/03043835(92)90019-R

28. Yi L, Su Q. Molecular mechanisms for the anti-cancer effects of diallyl disulfide. Food Chem Toxicol. 2013;57:362-370. doi:10.1016/ j.fct.2013.04.001

29. Hussien NI, Mousa AM, Shoman AA. Decreased level of plasma nesfatin-1 in rats exposed to cell phone radiation is correlated with thyroid dysfunction, oxidative stress, and apoptosis. Arch Physiol Biochem. 2020;1-7. doi:10.1080/13813455.2020. 1778037

30. Bonifácio BV, Silva PB, Ramos MA, Negri KM, Bauab TM, Chorilli M. Nanotechnology-based drug delivery systems and herbal medicines: a review. Int J Nanomedicine. 2014;9(1-15).

31. Falzon CC, Balabanova A. Phytotherapy: an introduction to herbal medicine. Prim Care. 2017;44(2):217-227. doi:10.1016/j.pop.20 17.02.001

32. Pain VM, Randall DP, Garlick PJ. Protein synthesis in liver and skeletal muscle of mice bearing an ascites tumor. Cancer Res. 1984;44(3):1054-1057.

33. Petruzzelli M, Wagner EF. Mechanisms of metabolic dysfunction in cancer-associated cachexia. Genes Dev. 2016;30(5):489-501. doi:10. $1101 / \operatorname{gad} .276733 .115$

34. Greten FR, Grivennikov SI. Inflammation and cancer: triggers, mechanisms, and consequences. Immunity. 2019;51(1):27-41. doi:10. 1016/j.immuni.2019.06.025

35. Gong C, Qi L, Huo Y, et al. Anticancer effect of limonin against benzo(a)pyrene-induced lung carcinogenesis in swiss albino mice and the inhibition of A549 cell proliferation through apoptotic pathway. J Biochem Mol Toxicol. 2019;33(12):e22374. doi:10.10 02/jbt.22374

36. Hassan SK, Mousa AM, El-Sammad NM, et al. Antitumor activity of cuphea ignea extract against benzo(a)pyrene-induced lung tumorigenesis in Swiss Albino mice. Toxicol Rep. 2019;6:1071-1085. doi:10.1016/j.toxrep.2019.10.004

37. Shahid A, Ali R, Ali N, et al. Methanolic bark extract of acacia catechu ameliorates benzo(a)pyrene induced lung toxicity by abrogation of oxidative stress, inflammation, and apoptosis in mice. Environ Toxicol. 2017;32(5):1566-1577. doi:10.1002/tox.22382

38. Sadeck NE, Ibrahim BM, Alassal MA. Cytochrome P450-isoenzyme $1 \mathrm{~A} 1$ in susceptibility to tobacco-related lung cancer. Asian Cardiovasc Thorac Ann. 2014;22(3):315-318. doi:10.1177/021849 2313492987

39. Kasala ER, Bodduluru LN, Barua CC, Sriram CS, Gogoi R. Benzo(a) pyrene induced lung cancer: role of dietary phytochemicals in chemoprevention. Pharmacol Rep. 2015;67(5):996-1009. doi:10.10 16/j.pharep.2015.03.004

40. Rao P, Midde N, Miller D, Chauhan S, Kumar A, Kumar S. Diallyl sulfide: potential use in novel therapeutic interventions in alcohol, drugs, and disease mediated cellular toxicity by targeting cytochrome P450 2E1. Curr Drug Metab. 2015;16(6):486-503. doi:10.2174/ 1389200216666150812123554

41. Hong Y-S, Park H-Y, Park -S-S. Diallyl sulfide down-regulates polycyclic aromatic hydrocarbon-induced cytochrome P450 1A1 in mouse liver and lung. Exp Mol Med. 1996;28(4):167-172. doi:10.1038/emm.1996.26

42. Asokkumar S, Naveenkumar C, Raghunandhakumar S, et al. Antiproliferative and antioxidant potential of beta-ionone against benzo(a)pyrene-induced lung carcinogenesis in swiss albino mice. Mol Cell Biochem. 2012;363(1-2):335-345. doi:10.1007/s11010011-1186-6 
43. Miao P, Sheng S, Sun X, Liu J, Huang G. Lactate dehydrogenase A in cancer: a promising target for diagnosis and therapy. IUBMB Life. 2013;65(11):904-910. doi:10.1002/iub.1216

44. Xie H, Hanai J, Ren J-G, et al. Targeting lactate dehydrogenase-a inhibits tumorigenesis and tumor progression in mouse models of lung cancer and impacts tumor-initiating cells. Cell Metab. 2014;19 (5):795-809. doi:10.1016/j.cmet.2014.03.003

45. Nikkhoo B, Sigari N, Ghaderi B, et al. Diagnostic utility of adenosine deaminase in serum and bronchoalveolar lavage fluid for screening lung cancer in Western Iran. J Med Biochem. 2013;32(2):109-115. doi:10.2478/jomb-2013-0011

46. Sauer AV, Brigida I, Carriglio N, Aiuti A. Autoimmune dysregulation and purine metabolism in adenosine deaminase deficiency. Front Immunol. 2012;3:265.

47. Jin N-Z, Zhu Y-P, Zhou J-W, et al. Preventive effects of quercetin against benzo[a]pyrene-induced DNA damages and pulmonary precancerous pathologic changes in mice. Basic Clin Pharmacol Toxicol. 2006;98(6):593-598. doi:10.1111/j.1742-7843.2006.pto_382.x

48. Sakthisekaran D, Rajendran P, Rengarajan T, Nishigaki I, Ekambaram G. Potent chemopreventive effect of mangiferin on lung carcinogenesis in experimental swiss albino mice. J Cancer Res Ther. 2014;10(4):1033-1039. doi:10.4103/0973-1482.137966

49. Nicco C, Laurent A, Chereau C, Weill B, Batteux F. Differential modulation of normal and tumor cell proliferation by reactive oxygen species. Biomed Pharmacother. 2005;59(4):169-174.

50. Reuter S, Gupta SC, Chaturvedi MM, Aggarwal BB. Oxidative stress, inflammation, and cancer: how are they linked? Free Radic Biol Med. 2010;49(11):1603-1616. doi:10.1016/j.freeradbiomed.20 10.09.006

51. Shadel G, Horvath T. Mitochondrial ROS signaling in organismal homeostasis. Cell. 2015;163(3):560-569. doi:10.1016/j.cell.2015.10. 001
52. Girija D, Ashaa S. Study of level of antioxidants in benzo[a]pyrene induced experimental lung cancer in swiss albino mice. J Pharm Res. 2011;4(7):2016-2018.

53. Oyewole AO, Birch-Machin MA. Mitochondria-targeted antioxidants. FASEB J. 2015;29(12):4766-4771. doi:10.1096/fj.15-275404

54. Bodduluru LN, Kasala ER, Madhana RM, et al. Naringenin ameliorates inflammation and cell proliferation in benzo(a)pyrene induced pulmonary carcinogenesis by modulating CYP1A1, NFאB and PCNA expression. Int Immunopharmacol. 2016;30:102-110. doi:10.1016/j. intimp.2015.11.036

55. Kasala ER, Bodduluru LN, Barua CC, Gogoi R. Antioxidant and antitumor efficacy of luteolin, a dietary flavone on benzo(a)pyrene-induced experimental lung carcinogenesis. Biomed Pharmacother. 2016;82:568-577. doi:10.1016/j.biopha.2016.05.042

56. Hudlikar RR, Pai V, Kumar R, et al. Dose-related modulatory effects of Polymeric Black Tea Polyphenols (PBPs) on initiation and promotion events in B(a)P and NNK-induced lung carcinogenesis. Nutr Cancer. 2019;71(3):508-523. doi:10.1080/01635581.2019.1578389

57. Nair P, Malhotra A, Dhawan DK. Curcumin and quercetin trigger apoptosis during benzo(a)pyrene-induced lung carcinogenesis. Mol Cell Biochem. 2015;400(1-2):51-56. doi:10.1007/s11010-014-2261-6

58. Orita H, Coulter J, Tully E, Kuhajda FP, Gabrielson E. Inhibiting fatty acid synthase for chemoprevention of chemically induced lung tumors. Clin Cancer Res. 2008;14(8):2458-2464. doi:10.1158/10780432.CCR-07-4177

59. Rahayu LS, Lukiati B, Nur AS, Rofiqotun Nurul Alimah A, Gofur A. Medicinal uses of single garlic in hyperlipidemia by fatty acid synthase enzyme inhibitory: molecular docking. IOP Conf Ser Earth Environ Sci. 2019;276:012008. doi:10.1088/1755-1315/276/1/012008

60. Yeh -Y-Y, Liu L. Cholesterol-lowering effect of garlic extracts and organosulfur compounds: human and animal studies. J Nutr. 2001;131(3):989s-993s. doi:10.1093/jn/131.3.989S
Journal of Inflammation Research

\section{Publish your work in this journal}

The Journal of Inflammation Research is an international, peerreviewed open-access journal that welcomes laboratory and clinica findings on the molecular basis, cell biology and pharmacology of inflammation including original research, reviews, symposium reports, hypothesis formation and commentaries on: acute/chronic inflammation; mediators of inflammation; cellular processes; molecular mechanisms; pharmacology and novel anti-inflammatory drugs; clinical conditions involving inflammation. The manuscript management system is completely online and includes a very quick and fair peerreview system. Visit http://www.dovepress.com/testimonials.php to read real quotes from published authors. 